\title{
THE BEHAVIOURAL INTENTION OF INVESTORS TO USE ISLAMIC BANKING'S INVESTMENT ACCOUNT PLATFORM (IAP) AS A SOURCE OF INVESTMENT PORTFOLIO: A STRUCTURAL EQUATION MODELING APPROACH
}

\author{
Mohamed Asmy bin Mohd Thas Thaker ${ }^{1}$ \\ Hassanudin bin Mohd Thas Thaker ${ }^{2}$
}

\begin{abstract}
As an alternative source of financing, Investment Account Platform (IAP) becomes a new phenomenon of raising financing for SMEs from a large pool of investors via the internet, and investment diversification portfolio tools among investors in Malaysia. The purpose of this study is to identify critical factors that influence behavioral intention of investors to invest in IAP's projects in Malaysia. The primary data ( $n=1000$ respondents) are collected from the investors in the Klang Valley, Malaysia and the analysis is conducted using Structural Equation Modeling (SEM). Furthermore, the model has validated its acceptance in the field by adopting the Technology Acceptance Model (TAM). This study has revealed that both the perceived usefulness and perceived easy to use are found to have a positive impact on the behavioral intention of investors to use IAP in Malaysia. Furthermore, perceived easy to use has a positive relationship and direct effect with perceived usefulness of investors to use IAP.
\end{abstract}

Keywords: Investment Account Platform, Financing, Investment

JEL Classification: E22, G24, M13, M14

Received: September 26, 2016; Revised: July 11, 2017;

Accepted: August 21, 2017

1 Department of Economics, Kulliyyah of Economics and Management Sciences, International Islamic University Malaysia, Jalan Gombak, 53100 Kuala Lumpur, Malaysia.

Email address: asmy@iium.edu.my

2 Department of Accounting and Finance, Faculty of Business, Accounting and Economics,

ELM Business School, HELP University, 50490 Kuala Lumpur, Malaysia

Email address: hans5587@hotmail.com 
114 The Behavioural Intention of Investors to Use Islamic Banking's Investment Account Platform (IAP) as a Source of Investment Portfolio: A Structural Equation Modeling Approach

\section{INTRODUCTION}

One of the sources of innovation, productivity and dynamism in both develop and developing countries is through small and medium enterprises (SMEs). Thus, access to capital becomes an integral part of transforming innovative ideas into sustainable businesses. Despite their potential importance for economic development, it is widely recognized that SMEs are facing difficulties in attracting external finance at the early and midst stages of the entrepreneurial lifecycle in many countries including in Malaysia.

There are considerable number of empirical studies that investigate the problem of assessing external finance by SMEs in Malaysia (Hashim, 1999; Saleh \& Ndubisi, 2006; Abdullah \& Mannan, 2010; SME Annual Report, 2010/2011; SME Annual Report, 2012/2013; SME Masterplan, 2012-2020; Aris, 2006). Those studies empirically have found that: (a) inadequate collateral; (b) insufficient legal status; (c) high transaction costs; (d) insufficient information and documentation; (e) no financial track record; ( $f$ ) nature and quality of business; ( $\mathrm{g}$ ) rigidity of the financing procedure; and (h) lack of awareness on financial facility are among the prominent factors that hindered SMEs from accessing external finance.

In addition, SMEs are characterised by high risk businesses and take many years to generate return to their investors. Lack of attraction and uncertainty of cash flows are also becoming limitation for them to access external finance. Due to such constraints, most formal investors such as retail investors, angel investors and sophisticated investors are unwilling to make proper investments at the pre-seed stage and focus their attention on later-stage businesses ventures with a proven business model. In order to address the issue of accessing external financing by the SMEs, the Malaysian government has introduced several financial assistance programs and allocations over the years to enhance financial accessibility.

For example, in 2013, the Government implemented a total of 139 programs with a financial commitment of RM9.9 billion for the SMEs. In addition, the Government is also working together with the private sector in undertaking another 15 programs which amount to RM8.5 billion of funding. Altogether, there are 154 programs 
amounting to RM18.4 billion. From these allocations, access to financing accounts for 38 percent of the total number of programs and 93 percent (RM9.2 million) of the total funds committed by the Government during the year (SME Annual Report 2012/2013). Although the government has allocated a huge amount for financial assistance and provided various programs for the SMEs, the effort is seen as being less effective when the impact from the business activities receiving this funding is found to be insignificant (Abdullah, Latif, Bakar, \& Nor, 2001). In spite of the Government's efforts to promote finan-cial accessibility through various measures, SMEs are still facing the problem of accessing external financing.

Given such scenario and to meet the need for financial accessibility by SMEs in Malaysia, alternative approach has been introduced and applied by selected Islamic financial institutions in Malaysia. Selected Islamic banks in Malaysia namely Affin Islamic Bank, Bank Muamalat Malaysia, Bank Islam Malaysia, Maybank Islamic, Bank Kerjasama Rakyat and Bank Simpanan Nasional have introduced Investment Account Platform (IAP). IAP was launched officially by ex-governor of Malaysian central bank, Dr. Zeti Akhtar Aziz on February17, 2016. The IAP is considered as an online platform that facilitate in channeling funds from investors to finance a viable ventures and SMEs. It is a technology-enabled marketplace for SMEs to raise funding from a large pool of investors for their businesses via the internet.

Despite its potential as source of raising fund for SMEs, to the best of researchers' knowledge, since IAP is still at its infant stage there are none of existing studies focused on the supply side, which has been largely ignored to date. The main relevant stakeholder of supply side in IAP is investors. Investors played a main role in providing a package of fund to demand side, which normally consist of businesses/SMEs. The former will invest their fund based on the project or businesses that they are interested in and getting the return after some periods.

However, none of study access the factors that influence the behavioral intention of investors (supply side) in contributing into IAP in Malaysia. According to Mollick (2014), this dearth of research on supply side particularly on investors' behaviour means that even a "basic academic knowledge of the dynamics of investors is 
116 The Behavioural Intention of Investors to Use Islamic Banking's Investment Account Platform (IAP) as a Source of Investment Portfolio: A Structural Equation Modeling Approach

lacking". The consequence of this dearth of research is that many aspects of IAP's investors remain poorly understood particularly their behavioural intention for undertaking IAP's projects.

In lieu with this, the present study seeks to shed light on the factors that influence the behavioral intention of investors to participate with IAP in Malaysia. By identifying and understanding of information particularly the behavior of investors, it will able to provide guidance especially to the policy maker in designing appropriate and better strategies in capturing investors' interest in IAP. Indeed, the research findings could also be part of the blueprints for market players and regulators in drafting the necessary regulations with regard to IAP.

Furthermore, the following investigation of the factors that influence the behavioural intention of investors to participate in IAP does not only represent a theoretical contribution by addressing an important research gap, it also provides practical insights for platform providers by improving their understanding of one of their important stakeholder.

\section{LITERATURE REVIEW}

The section on literatures divided into several parts; firstly it will introduce the overall journey of Islamic Banking and Finance (IBF) development in Malaysia. Later on, the discussion will continue with the conceptual explanation on Investment Account Platform (IAP). The third section reveals about the operationalization structure of IAP in Malaysia followed by the rationalization of having IAP in Malaysia as a source of creating funding for the ventures purpose. Last section will discuss the theory of Technology Acceptance Model (TAM) and hypotheses development.

\subsection{An Overview of Islamic Banking and Finance in Malaysia}

The development of Islamic Banking and Finance (IBF) in Malaysia has undergone four phases. First phase occurred in 1980s where the legislation was taking place for Islamic banking and Takaful. With the legislation, it allowed government to tap funding assistance 
which is Shariah complaint. Basically, in this phase, it is like building the foundation to build IBF.

In the next phase which taking place in 1990 where the designation of regulation and rules were established for the Islamic windows. The Shariah Advisory Council was developed by Bank Negara Malaysia (BNM) to overlook the progress and shariah aspect of IBF in Malaysia. In this phase, Islamic interbank market was also introduced and rapidly advanced.

In the following phase 2000 onwards specifically, in developing dual banking system and advance the development of IBF industry in general several initiative have been taken by BNM such as inviting foreign banks especially Islamic banks to operate in Malaysia and local banks are allowed to initiate the Islamic bank subsidiaries. In further strengthening the IBF, with the support from $B N M$, numerous talent institutions have been introduced to improve the development of human capital in IBF industry such as IBFIM, INCEIF, and ISRA. Moreover, the launches of Malaysia Industrial Development Finance Berhad (MIDF) has enabled to promote IBF at international level.

In 2010 onwards, the final phase, given the rapid advancement of technology due to globalisation, it has encourage the banks to use financial technology (FinTech) to carry out the transaction in various ways using technology. It has influence the Islamic banking as well especially in creating funding to the ventures. As per reported by IAP website (2016), the recognition of FinTech in IBF especially Investment Account (IA) which fall under IFSA has opened diversification opportunity to the Islamic banks in Malaysia.

As per rules stipulated in the Islamic Financial Act 2013 (IFSA), Islamic banks is allows to diversify their product innovation via investment account (IA) as substitute to raise fund from public. With this kind of speciality, it is noticed that both investors and public can realize significant advantage via risk-reward principle. In protecting the interest of investors, the coordination of Islamic banks especially in monitoring the entire process in IA by acting as intermediaries is very important.

Thus, in making sure that the IA can be successfully implemented and benefits to the entrepreneur society, the IAP, which is 
118 The Behavioural Intention of Investors to Use Islamic Banking's Investment Account Platform (IAP) as a Source of Investment Portfolio: A Structural Equation Modeling Approach

known as Investment Account Platform (IAP) has been introduced and taking place in the market. The IAP is expected to offers an investors a good platform where they can invest their fund in the productive place such as ventures that suit with their risk preference. With the introduction of IAP in the financial market, it further strengthening the position of IBF and contributes to the development of real economy.

\subsection{Investment Account Platform (IAP)}

By definition, IAP is known as a platform in obtaining funds from investors and channels it to finance specific projects or ventures. IAP is considered as a centralised platform among selected Islamic banks that is likely to have significant implications on the role of financial intermediation in the Islamic financial system. The platform of IAP was wholly owned by Raeed IAP Integrated Sdn Bhd and collaborated by six Islamic banks, namely, Affin Islamic Bank Bhd, Bank Islam Malaysia Bhd, Bank Mualamat Malaysia Bhd, Maybank Islamic Bhd, Bank Kerjasama Rakyat, and Bank Simpanan Nasional.

This is a newly Fintech innovative product offered by Islamic banking in Malaysia. Although IAP has some similarities with existing products such as crowd funding and peer-to-peer financing, IAP is like direct financing performed by investors for the project that suit with their taste and preferences. IAP enables Islamic banks to perform their intermediation role in the operationalisation of the investment accounts that are being offered on this platform, would rigorously undertake the credit assessment and screening of the listed ventures. The IAP would also require ratings on the listed ventures by rating agencies (Rating Agency Malaysia) reinforced by the requirement for such ventures to comply with the disclosure standards thus enabling investors to make informed decisions.

This platform provides mechanism for regular monitoring of the progress of the ventures, thus allowing for assessments to be undertaken by the sponsoring banks of any emerging risks associated with the ventures. Thus, by IAP, it is expected to advantage to SMEs, who looks for financial support from banks. The advantages of IAP are as follows: 
a. IAP allows investor to channel the funds based on their capability and choices of ventures.

b. IAP creating a contractual relationship between investors and Islamic banks.

c. Investors may be advised by Islamic bank with regard to the investment tenure or duration and the industry that they prefer to invest in.

d. The return from IAP depend on the performance of underlying ventures (Islamic banks with sign a new agreement with venture owner to dispense return.

e. However, IAP is not guaranteed by PIDM, which means the capital is not protected.

\subsection{Operationalization of IAP in Malaysia}

The following Figure 1 depicts the illustration of how the IAP has been structured in Malaysia. Basically, the source of fund comes from various parties such as individual, corporate and institutional investors. Usually they will channel fund to the projects or ventures that they have chosen.

The following process is deals with Islamic banking where they will perform duties such as monitor the performance, assess the project suitability, etc. Upon finishing the screening of project or ventures, then the Islamic banking will channel the financing to the ventures that required the fund. Obviously, this will be facilitated by the platform in smoothing up the entire process. See Figure 1 for the illustration of IAP in Malaysia (https://www.iaplatform.com/). 
120 The Behavioural Intention of Investors to Use Islamic Banking's Investment Account Platform (IAP) as a Source of Investment Portfolio: A Structural Equation Modeling Approach

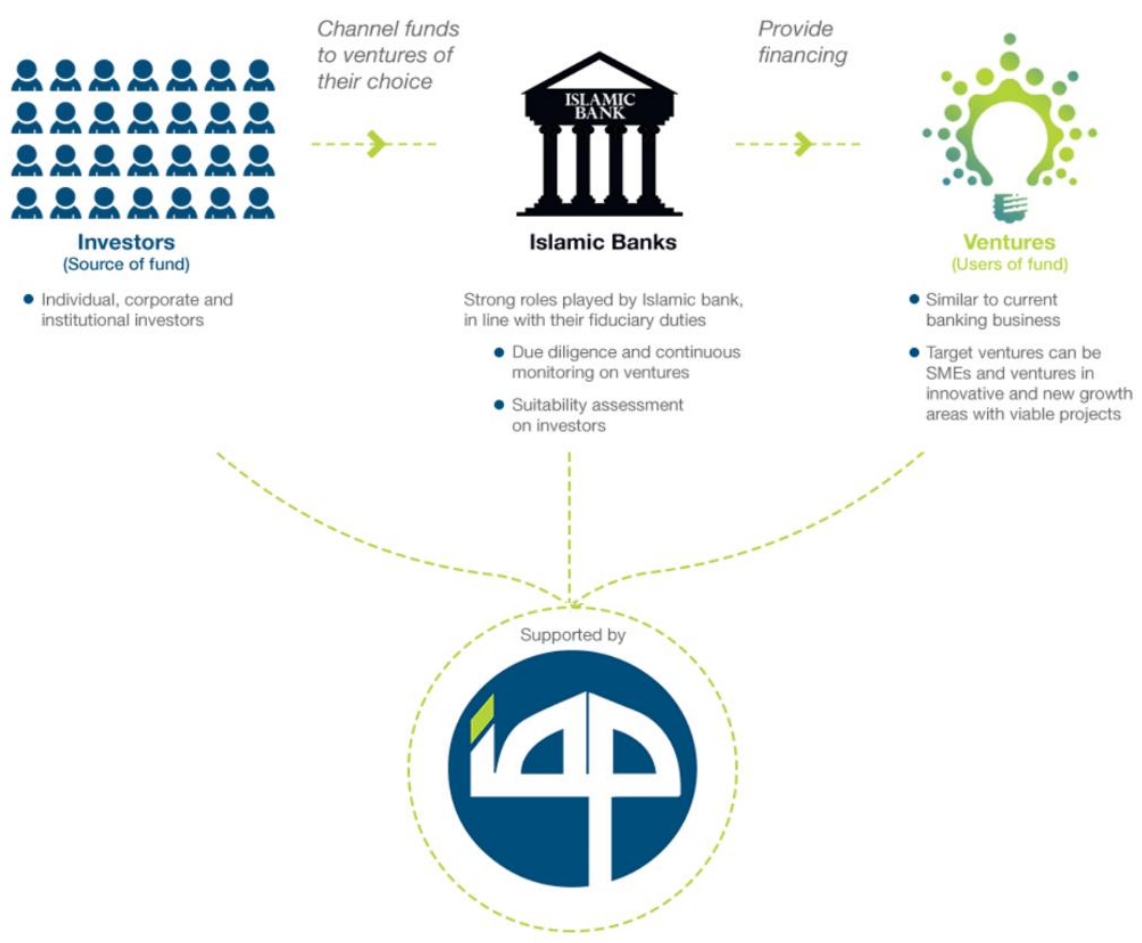

Figure 1.

Operationalization of IAP

Source: https://www.iaplatform.com/

The key characteristics of IAP are as follows:

a. The mode of financing is shariah compliant.

b. Consistent with current regulations of Islamic financing where it is regulated by Islamic Financial Services Act (IFSA, 2013).

c. Ventures that participating in the transaction will undergo screening procedure which is called credit assessment.

d. Ventures selected will also undergo rating process to measuring risk-return profiling of the ventures.

e. Compliance to disclosure standard to increase the transparency level of the ventures.

f. Flexible and user friendly as it meet the criteria of Fintech.

g. Open to different types ventures that have bright future. 


\subsection{Rationalization of IAP}

One of the rationalizations of IAP would be in terms of competitive financing terms and conditions. The application of financing by ventures can process and assessed by all banks that participating in the operation. Simultaneously, the ventures owner can choose the financing that they preferred. Secondly, with IAP, it can possibly apply for all types of financing regardless whether they are debt based financing, equity based or mixed of debt and equity (called as hybrid). As reported in their official website, IAP gives full accessibility for all type of investors (both individual and institutional investors).

In addition, it is a platform where can be accessed anytime, anywhere by using online. The IAP also expected to bring foreign investors, thus increasing the inflow of cash to the country as government do not placed any restriction on foreign capital inflow into the IAP. Interestingly, the profit obtained will be exempted from income tax for the first three years (Sipalan, 2016). Finally, with IAP, there will existence of public-private partnerships in financing ventures. With collaboration with IAP, government also can effectively identify the proper projects or ventures and conduit their grant into. In addition, government also can invite private sectors to contribute fully or partially the funds to the ventures. With this kind of arrangement, it can make the economic become more prosperous and productive.

\subsection{Technology Acceptance Model (TAM) and Hypotheses Development}

The Technology Acceptance Model (TAM) has been recognised as a useful model of technology acceptance behaviours in a variety of information system or information technology contexts. According to Davis (1989), Theory of Reasoned Action (TRA) introduced by Fishbein and Ajzen's (1975) represents the theoretical basis of TAM. According to TRA, a person's performance of a specified behaviour is determined by the intention to perform it. Meanwhile, TAM is one of the most influential approach of the determinants of information systems and information technology acceptance to predict the 
122 The Behavioural Intention of Investors to Use Islamic Banking's Investment Account Platform (IAP) as a Source of Investment Portfolio: A Structural Equation Modeling Approach

intention to use and acceptance of information systems and information technology by individuals (Chen, Li, \& Li, 2011).

TAM incorporates two belief variables that relevant and represents primary drivers of technology users' acceptance of new information technology namely perceived usefulness and perceived ease of use. Perceived usefulness is defined as the degree to which a person believes that using a particular system would enhance his or her job performance. On the other hand, perceived ease of use is defined as the degree to which a person believes that using a particular system would be free from effort (Davis, 1989). Perceived ease of use has both an immediate effect and an indirect effect on adoption intention via perceived usefulness; therefore, this construct has effects on both perceived usefulness and attitude (Davis, 1993; Venkatesh \& Davis, 2000).

TAM is known as an intention-based model predictor because it states that the intention to adopt a technology is a good predictor of its actual usage through perceived ease of use and perceived usefulness. Many researchers have conducted empirical studies to examine the explanatory power of TAM, producing relatively consistent results on the acceptance behaviour of information technology end users (Igbaria, Zinatelli, Cragg, \& Cavaye, 1997; Venkatesh \& Davis, 2000; Horton, Buck, Waterson, \& Clegg, 2001). According to Chang and Tung (2008), researchers agree that TAM is valid in predicting the individual acceptance of numerous systems including technological based system and information technologybased system (Chin \& Todd, 1995; Segars \& Grover, 1993).

Realizing the application of the TAM in various fields, this study aimed for the additional contribution of TAM in the area of Investment Account Platform (IAP). To the best knowledge of the researcher, there has been no any empirical research conducted to examine the behavioural intention of investors to use IAP and tested the particular model using TAM. Thus, the present research is designed to test empirically the behavioural intention of investors to use IAP in Malaysia, as shown in Figure 2. 


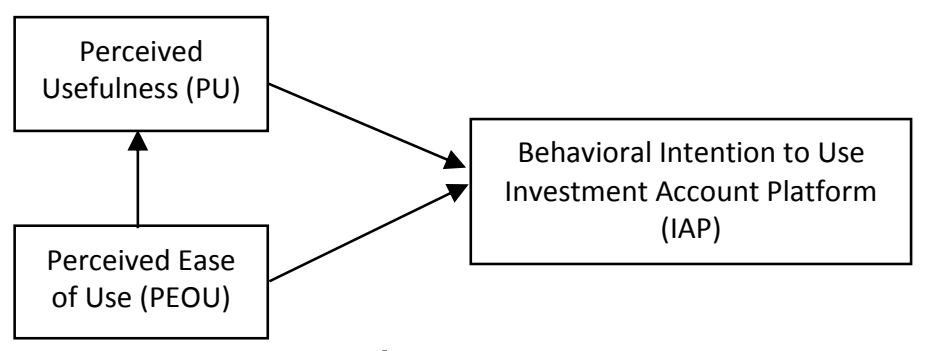

Figure 2.

Technology Acceptance Model (TAM)

Source: Author's illustration

Based on TAM framework, the present study comes out with three main hypotheses, which are:

(i) Hypothesis 1

Ho: There is no significant (positive) influence of perceived usefulness on the intention to engage in Investment Account Platform (IAP) among investors.

$\mathrm{Ha}$ : There is a significant (positive) influence of perceived usefulness on the intention to engage in Investment Account Platform (IAP) among investors.

(ii) Hypothesis 2

Ho: There is no significant (positive) influence of perceived ease of use on the intention to engage in Investment Account Platform (IAP) among investors.

$\mathrm{Ha}$ : There is a significant (positive) influence of perceived ease of use on the intention to engage in Investment Account Platform (IAP) among investors.

(iii) Hypothesis 1

Ho: There is no significant (positive) influence of perceived ease of use on perceived usefulness of Investment Account Platform (IAP) among investors.

$\mathrm{Ha}$ : There is a significant (positive) influence of perceived ease of use on perceived usefulness of Investment Account Platform (IAP) among investors. 
124 The Behavioural Intention of Investors to Use Islamic Banking's Investment Account Platform (IAP) as a Source of Investment Portfolio: A Structural Equation Modeling Approach

\section{RESEARCH METHODS}

\subsection{Data Collection Procedure and Sample}

Data are collected using purposive sampling method from investors in the Klang Valley (Selangor and Kuala Lumpur), who are above 18 years old. According to the statistics by Department of Statistics Malaysia, there are about 5.5 million population, who are above 18 years old and living at Klang Valley. Around 1400 investors are sent the questionnaire. A total of 1260 questionnaires are returned, where 1000 (71 percent) are usable for data analysis purpose.

The behavioural intention of investors to using Investment Account Platform (IAP) was tested by using Structural Equation Modeling (SEM). SEM is distinctive in its ability to examine a series of dependence relationships simultaneously. It is useful in testing theories which have multiple equations involving dependence relationships. This study used two-stage SEM approach, which involves Confirmatory Factor Analysis (CFA) using measurement model and structural or path analysis of hypothesized relationships using structural model. The use of this statistical tool become widely acceptable and tested in social science researches. This method allows the researchers to assess and modify the theoretical models which provide opportunities to explore new relationship development within the model of theory (Anderson \& Gerbing, 1988).

\subsection{Research Instruments}

This study adopts a self-administered questionnaire design. The questionnaires are adopted and adapted based on Technology Acceptance Model (TAM). All constructs and the items are adapted from extant literatures and were modified to suit the purpose of this study. All major scale items are based on a five-point Likert-scale ranging from strongly disagree (1) to strongly agree (5).

In terms of items development, they are adapted from Davis (1989), Kripanot (2007), Willis (2008), Cowen (2009), and Chandio (2011). Perceived usefulness consists of (8-item), perceived ease of use consists of (12-item) and behavioural intention consists of (9item). 


\subsection{Data Analysis}

The collected data was analysed using SPSS Statistics 20 and AMOS 20. Following the procedure suggested by Anderson and Gerbing (1988), a measurement model was estimated before the structural model. A confirmatory factor analysis (CFA) was employed to assess the measurement model and to test data quality, including reliability and construct validity checks. Structural equation modelling (SEM) was conducted to assess overall fit of the proposed model and test hypotheses.

\section{RESULTS, FINDINGS, AND DISCUSSION}

Around 1000 respondents participated in this research. Based on Table 1, most of the respondents (56.7\%) were female followed by male of $43.3 \%$. Almost three-quarters $(79.6 \%)$ of the respondents are between the age group of 20-40, few are over 40 years of age $(20.4 \%)$. There was a majority of $57.2 \%$ respondents are single, followed with $40.1 \%$ and 2.7 respondents are married and divorced, respectively.

Besides, in terms of educational level, majority of respondents are well educated, with almost $17.6 \%$ holding a college diploma or matriculation and about $65.6 \%$ holding at least a bachelor degree or above. Most of the respondents (27.2\%) were working at private sector followed with $16.9 \%$ were working at public sector. $41.5 \%$ of the respondents were students and 3.9\% were housewife. Only $2.3 \%$ of the respondents were retired. Meanwhile, majority of respondents $(61.9 \%)$ are in the income group of less than RM3000. The remaining $38.1 \%$ of the surveyed respondents fall in more than RM3000 income group. 
126 The Behavioural Intention of Investors to Use Islamic Banking's Investment Account Platform (IAP) as a Source of Investment Portfolio: A Structural Equation Modeling Approach

Table 1.

Distribution of Respondents by Gender, Age and Marital Status

\begin{tabular}{cccc}
\hline & & Frequency & $\%$ \\
\hline \multirow{2}{*}{ Gender } & Male & 433 & 43.3 \\
& Female & 567 & 56.7 \\
\hline \multirow{3}{*}{ Age Group } & $20-30$ & 583 & 58.3 \\
& $31-40$ & 213 & 21.3 \\
& $41-50$ & 147 & 14.7 \\
\hline \multirow{3}{*}{ Marital Status } & Above 50 & 57 & 5.7 \\
\hline \multirow{4}{*}{ Educational Level } & Single & 572 & 57.2 \\
& Married & 401 & 40.1 \\
& Divorced & 27 & 2.7 \\
\hline \multirow{4}{*}{ Occupational } & No Education & 22 & 2.2 \\
& Secondary School & 146 & 14.6 \\
& Diploma & 176 & 17.6 \\
& Bachelor & 588 & 58.8 \\
& Postgraduate (Master or PhD) & 68 & 6.8 \\
\hline & Public & 169 & 16.9 \\
& Private & 272 & 27.2 \\
& Self employed & 82 & 8.2 \\
& Housewife & 39 & 3.9 \\
& Student & 415 & 41.5 \\
& Retired & 23 & 2.3 \\
\hline \multirow{4}{*}{ Income Level } & 307 & 30.7 \\
& Less than RM1000 & 168 & 16.8 \\
& RM1001- RM2000 & 144 & 14.4 \\
& RM2001- RM3000 & 130 & 13 \\
& RM3001- RM4000 & 105 & 10.5 \\
& RM4001- RM5000 & 146 & 14.6 \\
\hline & More Than RM5000 & &
\end{tabular}

\subsection{Structural Equation Modelling}

\subsubsection{Measurement Model}

The initial measurement model incorporates three latent constructs indicated by respective items pertaining to each scale: perceived usefulness (PU), perceived easy to use (PEU), and behavioural intention (BI) (see Figure 3 for the initial measurement model). The results of goodness-of-fit indices for the initial measurement model are given in the following Table 2 . 


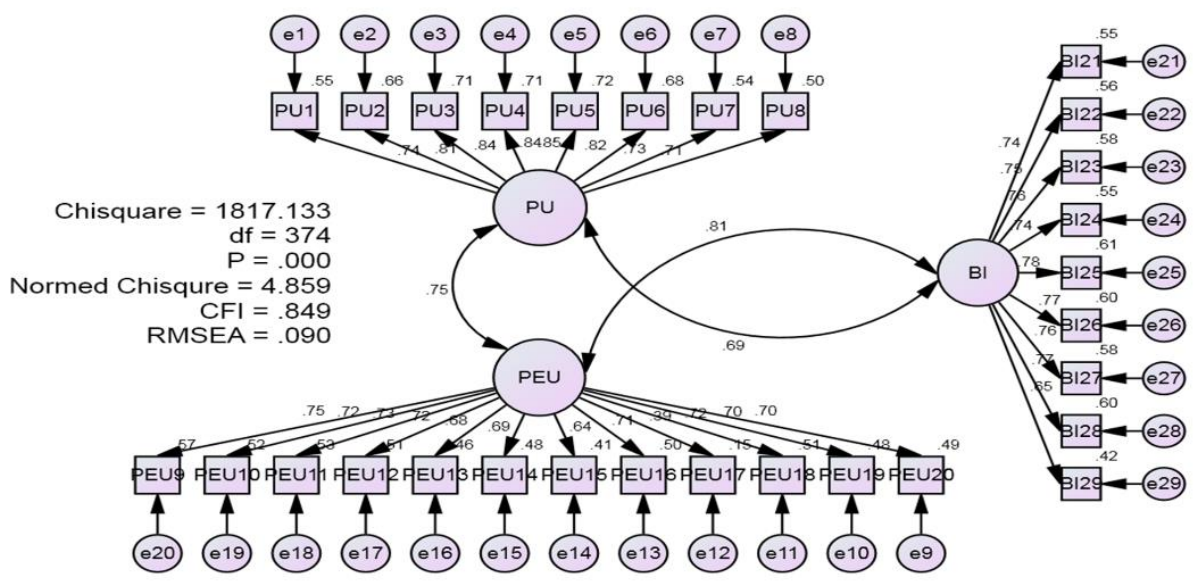

Figure 3.

Initial Measurement Model (MM1)

Table 2.

Fit Indices for MM1

\begin{tabular}{ccccccc}
\hline Model & $\chi^{2}$ & Df & Normed $\chi^{2}$ & RMSEA & CFI & Comment \\
\hline MM1 & 1817.133 & 374 & 4.859 & 0.090 & 0.849 & $\begin{array}{c}\text { Do not achieve } \\
\text { required level }\end{array}$ \\
\hline
\end{tabular}

As shown in Figure 3 and Table 2, certain fitness indexes for the initial measurement model do not achieve the required level. It can be seen from MM1 where the CFI is incremental fit index with a value of 0.880 and this value has fallen below the recommended level of 0.90 . For the badness-of-fit-index, RMSEA has the value of 0.090 which exceeds the required value that is below 0.08 cut-off value suggested by Browne and Cudeck (1993).

Meanwhile, the factor loading for selected items are below 0.70 , after several run of measurement models. These items have caused the measurement model for the constructs to be poorly fit. It is therefore suggested that these items need to be deleted and the new measurement model needs to be run until the factor loading is above 0.70 for each item. Now, after deleting few items (namely PEU 13, PEU 14, PEU 15, PEU 16, PEU 17, PEU 18, PEU 19 PEU 20 and BI29) due to low factor loading (less than 0.70), the new measurement model is run and shown in Figure 4. 


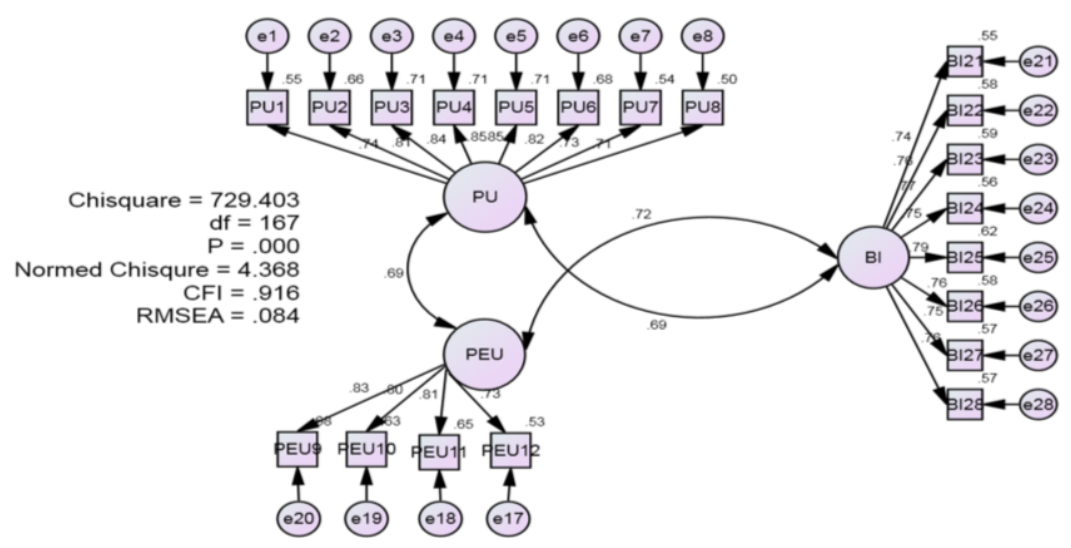

Figure 4.

Measurement Model 2

Table 3.

Fit Indices for MM2

\begin{tabular}{ccccccc}
\hline Model & $\chi^{2}$ & Df & Normed $\chi^{2}$ & RMSEA & CFI & Comment \\
\hline MM2 & 729.403 & 167 & 4.368 & 0.084 & 0.916 & $\begin{array}{c}\text { Do not achieve } \\
\text { required level }\end{array}$ \\
\hline
\end{tabular}

After deleting the few items and running the new measurement model, the results of fit indices are still below the required level although the factor loading for all items are above 0.70 as shown in Table 3 . The indices improved slightly and do not bring significant change to the fit indices after dropping four items. The Normed Chi-Square $\left(x^{2} / \mathrm{df}\right)$ shows a value of 6.144 (above required value which is less than 5.0 ) followed with the CFI which is 0.937 (fulfill the criteria which is above 0.90 ). Meanwhile, RMSEA value is 0.084 also improved slightly and above the required value which is 0.08 following the cut-off value suggested by Browne and Cudeck (1993). Thus, it shows that there is redundancy among the items in the measurement model. For the items redundancy, it can be observed through checking the Modification Indices (MI).

According to Awang (2012), in dealing with high $\mathrm{Ml}$ and redundancy among items, the researcher has two options which are: (a) to delete one of two redundant items and run the new measurement model; or (b) to set these two correlated measurement 
errors of redundant items as a ' free parameter' and run the new measurement model. This study opts for the second option which involves the correlation measurement errors of redundant items. After a few correlated measurement errors of redundant items, the new measurement model is performed and the result is presented in the following diagram (Figure 5) and Table 4.

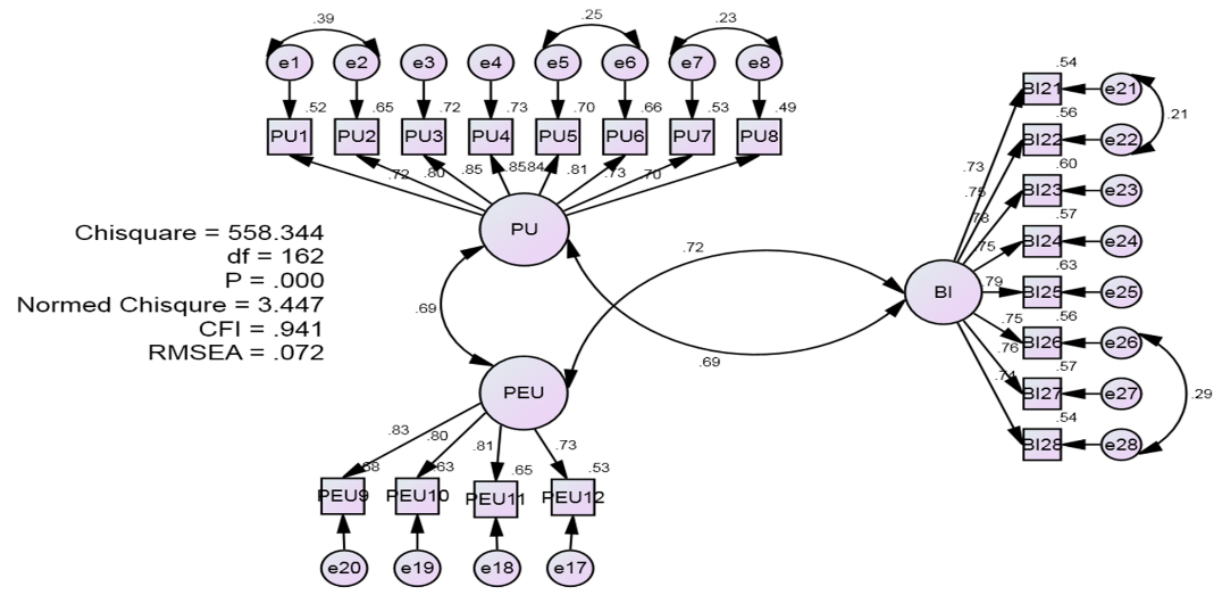

Figure 5.

Final Measurement Model 3

Table 4.

Fit Indices for Final MM3

\begin{tabular}{ccccccc}
\hline Model & $\chi^{2}$ & Df & Normed $\chi^{2}$ & RMSEA & CFI & Comment \\
\hline Final MM3 & 558.34 & 162 & 3.447 & 0.072 & 0.941 & $\begin{array}{l}\text { The required } \\
\text { level is achieved }\end{array}$ \\
\hline
\end{tabular}

As shown in Table 4, the fit indices for the final measurement model improved after these modifications were made. Final measurement model 3 presented a much more reasonable fit for the data. The Normed $\chi^{2}$ value achieved 3.447 which fulfils the required level which is to be less than 5.0. Furthermore, CFI value has value of 0.941 which is more than the required cut-off point of 0.9 . The RMSEA value is 0.072 and this value falls below the 0.08 cut-off point suggested by Browne and Cudeck (1993). 
Once the CFA procedure for every measurement model is completed, the following steps are performed to compute certain measures which access the validity and reliability of the construct. Thus, in the subsequent section, it shows the results of construct validity.

Meanwhile, as shown in Table 5, the construct reliability values were well above the 0.70 level suggested by Nunnally (1978). All standardized factor loadings emerged fairly high and significant, ranging from 0.70 to 0.853 . This suggested convergence of the indicators with the appropriate underlying factors (Anderson \& Gerbing, 1988). The average variance extracted (AVE) values for each construct were all above 0.50 (Fornell \& Larcker, 1981). Overall, these results showed strong evidence of the uni-dimensionality, reliability, and validity of the measures.

Discriminant validity of the constructs is shown in Table 6 . Smith, Milberg, and Burke (1996) proposed that each construct's AVE is compared to its Squared Correlation (SC) with other constructs. In this regard, if the average variance extracted of a factor is greater than the squared correlation between that and every other factor, the factor exhibit discriminant validity. The result shows the square root of the AVE between each pair of factors that was higher than the squared correlation estimated between factors, thus ratifying its discriminant validity (Hair, Black, Babin, Anderson, \& Tatham, 2006).

Table 5.

The CFA Results for the Measurement Model

\begin{tabular}{cccccc}
\hline Construct & Items & $\begin{array}{c}\text { Factor } \\
\text { Loading }\end{array}$ & $\begin{array}{c}\text { Cronbach } \\
\text { Alpha } \\
\text { (Above 0.7) }\end{array}$ & $\begin{array}{c}\text { CR } \\
\text { (Above 0.6) }\end{array}$ & $\begin{array}{c}\text { AVE } \\
\text { (Above 0.5) }\end{array}$ \\
\hline $\begin{array}{c}\text { Perceived } \\
\text { Usefulness }\end{array}$ & PU1 & 0.721 & 0.931 & 0.929 & 0.623 \\
(PU) & PU2 & 0.803 & & & \\
& PU3 & 0.848 & & & \\
& PU4 & 0.853 & & & \\
& PU5 & 0.838 & & & \\
& PU6 & 0.809 & & & \\
& PU7 & 0.726 & & & \\
Perceived & PU8 & 0.70 & & & \\
Ease Of Use & PEU9 & 0.827 & 0.867 & & \\
(PEU) & PEU10 & 0.796 & & & \\
& PEU11 & 0.805 & & & \\
& PEU12 & 0.728 & & & \\
\end{tabular}




\begin{tabular}{cccccc}
\hline Behavioural & & & 0.916 & 0.914 & 0.572 \\
Intention (BI) & BI21 & 0.731 & & & \\
& BI22 & 0.751 & & & \\
& BI23 & 0.776 & & \\
& BI24 & 0.755 & & \\
& BI25 & 0.795 & & \\
& BI26 & 0.748 & & \\
& BI27 & 0.755 & & \\
BI28 & 0.736 & & \\
\hline
\end{tabular}

Table 6.

Inter-construct Correlation and Squared Correlation (SC)

\begin{tabular}{cccc}
\hline $\begin{array}{c}\text { Average Variance } \\
\text { Extracted (AVE) }\end{array}$ & $\begin{array}{c}\mathrm{BI} \\
(0.572)\end{array}$ & $\begin{array}{c}\text { PU } \\
(0.623)\end{array}$ & $\begin{array}{c}\text { PEU } \\
(0.624)\end{array}$ \\
\hline BI & 1 & & \\
PU & 0.687 & 1 & \\
SC & $(0.472)$ & & \\
PEU & 0.725 & 0.693 & 1 \\
SC & $(0.523)$ & $(0.480)$ & \\
\hline
\end{tabular}

\subsubsection{Structural Model}

A structural model was estimated to test the hypotheses from Ha1, $\mathrm{Ha} 2$ and Ha3. The goodness-of-fit statistics of the proposed model showed that the model reasonably fits the current data. Chi-square value of the model $\left(x^{2}=558.344, \mathrm{df}=162, \mathrm{p}=0.000\right)$ and other goodness of fit indices (Normed $\chi^{2}=3.447 ;$ RMSEA $=0.072 ; \mathrm{CFI}=$ $0.941)$ revealed that the model fit the data reasonably well. The structural results of the proposed model are depicted in Figure 6.

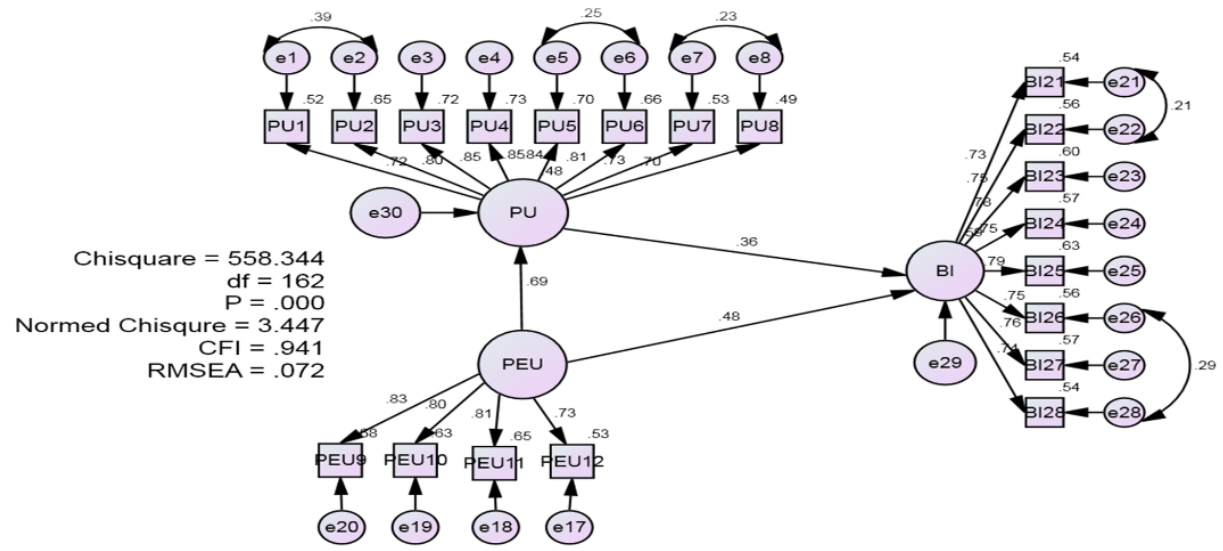

Figure 6.

Structural Model 
The path coefficients of the structural model have been measured to assess the statistical significance of the path coefficients (please see Table 7). The results revealed that perceived usefulness and perceived easy to use has a positive relationship with behavioral intention of investors to use Investment Account Platform (IAP) with $b=0.320, p<0.05$ and $b=0.445$, $p<0.05$, respectively. In addition, perceived easy to use has a positive relationship and direct effect with perceived usefulness with $b=0.715$ and significant at $\mathrm{p}<0.05$. Thus, $\mathrm{H1}, \mathrm{H} 2$, and $\mathrm{H} 3$ are supported. Table 7 shows the results.

Table 7.

The Results of Structural Model

\begin{tabular}{cccccc}
\hline Hypothesis & Relationship & Beta & t-Value & p-Value & Decision \\
\hline H1 & PU $->$ BI & 0.320 & 6.097 & 0.000 & Supported \\
H2 & PEU $\rightarrow$ BI & 0.445 & 7.802 & 0.000 & Supported \\
H3 & PEU $\rightarrow$ PU & 0.715 & 12.396 & 0.000 & Supported \\
\hline
\end{tabular}

Based on these results, the behavioural intention of investors to use Investment Account Platform (IAP) was found to depend on perceived usefulness and perceived easy to use. Perceived usefulness is the perception that a given a technological-based system, it will help a user achieve his or her work goals. The investors need a mechanism that could help them to assist entrepreneurs or SMEs by contributing capital for their businesses. Thus, by using Investment Account Platform (IAP) which is through online platform, it will help investors to assist entrepreneurs or SMEs to contribute capital for their businesses in Malaysia. This finding is consistent with Venkatesh and Davis (2000), Abbasi, Chandio, Soomro, and Shah (2011), and Cheng, Lam, and Yeung (2006).

On the other hand, perceived ease of use is defined as the degree to which a person believes that easy-to-use technology was associated with greater intent to use it (Davis, 1989). Thus, the easier to involve with Investment Account Platform (IAP), it will attract more investors' intention to assist entrepreneurs or SMEs by contributing capital for their businesses in Malaysia. This finding is also similar to Davis (1989), Gefen and Straub (2004), and Yi and Hwang (2003). Meanwhile, perceived ease of use was positively associated with perceived usefulness. It means that the easier the system was to use, the more useful it was perceived to be. Thus, 
Investment Account Platform (IAP) may need to have the features that useful to the user particularly the investors.

\section{CONCLUSION AND RECOMMENDATION}

Investment Account Platform (IAP) become a platform for investors, who are keen to diversify their investment portfolio. Indeed, IAP may be a cost-efficient deal origination platform for investors. This study has examined the behavioural intention of investors to use Investment Account Platform (IAP). The findings have proven that both perceived usefulness and perceived ease of use are directly significant in influencing the investors' intention to use Investment Account Platform (IAP).

The findings of this study can be used to develop a specific framework in which to examine other components of using Investment Account Platform (IAP)'s behavior and to plan appropriate intervention strategies to increase its capacity in assisting SMEs to access to external finance in Malaysia. 
134 The Behavioural Intention of Investors to Use Islamic Banking's Investment Account Platform (IAP) as a Source of Investment Portfolio: A Structural Equation Modeling Approach

\section{REFERENCES}

Abbasi, M. S., Chandio, F. H., Soomro, A. F., \& Shah, F. (2011). Social influence, voluntariness, experience and the internet acceptance: An extension of technology acceptance model within a South-Asian country context. Journal of Enterprise Information Management, 24(1), 30-52.

Abdullah, M., Latif, A. L., Bakar, M. I., \& Nor, A. M. (2001). The outreach of support programs for bumiputra's entrepreneurs in SMEs: Evidence from Malaysia.

Abdullah, M. A., \& Manan S. K. A. (2010). Adequacy of financial facilities for small-medium business: Empirical findings from Malaysia. International Review of Business Research Papers, 6(4), 535-548.

Anderson, J. C., \& Gerbing, D. W. (1988). Structural Equation Modelling in practice: A review and recommended two-step approach. Psychological Bulletin, 103(3), 411-423.

Aris, N. M. (2006, September). SMEs: Building blocks for economic growth. Paper presented at National Statistics Conference, Department of Statistics, Malaysia, 4-5 September 2006.

Awang, Z. H. (2012). A handbook on SEM Structural Equation Modeling. Shah Alam, Selangor Darul Ehsan: UiTM.

Browne, M. W., \& Cudeck, R. (1993). Alternative ways of assessing model fit. Sage Focus Editions, 154, 136-136.

Chang, S. C., \& Tung, F. C. (2008). An empirical investigation of students' behavioural intentions to use the online learning course websites. British Journal of Educational Technology, 39(1), 71-83.

Chen, S. C., Li, S. H., \& Li, C. Y. (2011). Recent related research in technology acceptance model: A literature review. Australian Journal of Business and Management Research, 1(9), 124-127. 
Cheng, T. C. E., Lam, D. Y. C., \& Yeung, A. C. L. (2006). Adoption of internet banking: An empirical study in Hong Kong. Decision Support Systems, 42(3), 1558-1572.

Chin, W. C., \& Todd, P. A. (1995). On the use, usefulness and ease of use of structural equation modeling in MIS research: A note of caution. MIS Quarterly, 19(2), 237-246.

Cowen, J. B. (2009). The influence of perceived usefulness, perceived ease of use, and subjective norm on the use of computed radiography systems: A pilot study (Unpublished Phd Thesis). The Ohio State University College of Medicine.

Chandio, F. H. (2011). Studying acceptance of online banking information system: A Structural Equation Model (Unpublished Phd Thesis). Brunel University.

Davis, F. D. (1989). Perceived usefulness, perceived ease of use, and user acceptance of information technology. MIS Quarterly, 13(3), 319-340.

Davis, F. D. (1993). User acceptance of information technology: System characteristics, user perceptions and behavioral impacts. International Journal of Man-Machine Studies, 38(3), 475-487.

Fishbein, M., \& Ajzen, I. (1975). Belief, attitude, intention and behaviour: An introduction to theory and research. Addison-Wesley Pub. Co.

Fornell, C., \& Larcker, D. F. (1981). Structural Equation Models with unobservable variables and measurement error: Algebra and statistics. Journal of Marketing Research, 18(3), 382-388.

Gefen, D., \& Straub, D. W. (2004). Consumer trust in B2C e-commerce and the importance of social presence: Experiments in e-products and e-services. Omega, 32(6), 407-424.

Hair, J. F., Black, W. C., Babin, B., Anderson, R. E., \& Tatham, R. L. (2006). Multivariate data analysis (6 $6^{\text {th }}$ ed.). New Jersey: Prentice Hall.

Hashim, M. K. (1999). A review of the role of SMEs in the manufacturing sector in Malaysia. Malaysian Management Review, 34(1), 40-49. 
Horton, R. P., Buck, T., Waterson, P. E., \& Clegg, C. W. (2001). Explaining intranet use with the technology acceptance model. Journal of Information Technology, 16(4), 237-249.

Https://www.iaplatform.com. Retrieved June 11, 2016.

Igbaria, M., Zinatelli, N., Cragg, P., \& Cavaye, A. L. M, (1997). Personal computing acceptance factors in small firms: A Structural Equation Model. MIS Quarterly, 21(3), 279-305.

Kripanont, N. (2007). Examining a technology acceptance model of internet usage by academics within Thai business schools. (Unpublished Phd Thesis). Victoria University.

Mollick, E. (2014). The dynamics of crowdfunding: An exploratory study. Journal of Business Venturing, 29(1), 1-16.

National SME Development Council. (2011). SME annual report 2010/2011: Leveraging opportunities realizing growth. Kuala Lumpur, Malaysia.

National SME Development Council. (2012). SME masterplan 20122020: Catalysing growth and income. Kuala Lumpur, Malaysia.

National SME Development Council. (2013). SME annual report 2012/2013: Embracing changes. Kuala Lumpur, Malaysia.

Nunnally, J. C. (1978). Psychometric methods. New York: Mcgraw Hill.

Saleh, A. S., \& Ndubisi, N. O. (2006). An evaluation of SME development in Malaysia. International Review of Business Research Papers, 2(1), 1-14.

Segars, A. H., Grover, V., (1993). Re-examining perceived ease of use and usefulness: A Confirmatory Factor Analysis. MIS Quarterly, 17(4), 517-525.

Sipalan J. (2016). Malaysian Islamic banks launch Investment Account Platform. Retrieved July 5, 2016 from http://reut.rs/1Q0HouG on.

Smith, H. J., Milberg, S. J., \& Burke, S. J. (1996). Information privacy: measuring individuals' concerns about organizational practices. MIS Quarterly, 20(2), 167-196. 
Venkatesh, V., \& Davis, F. D. (2000). A theoretical extension of the technology acceptance model: Four longitudinal field studies. Management Science, 46(2), 186-204.

Willis, T. J. (2008). An evaluation of the technology acceptance model as a means of understanding online social networking behavior (Unpublished Dissertation). University of South Florida.

Yi, M. Y., \& Hwang, Y. (2003). Predicting the use of web-based information systems: Self-efficacy, enjoyment, learning goal orientation, and the technology acceptance model. International Journal of Human-Computer Studies, 59(4), 431-449. 
138 The Behavioural Intention of Investors to Use Islamic Banking's Investment Account Platform (IAP) as a Source of Investment Portfolio: A Structural Equation Modeling Approach

This is page intentionally left blank 